
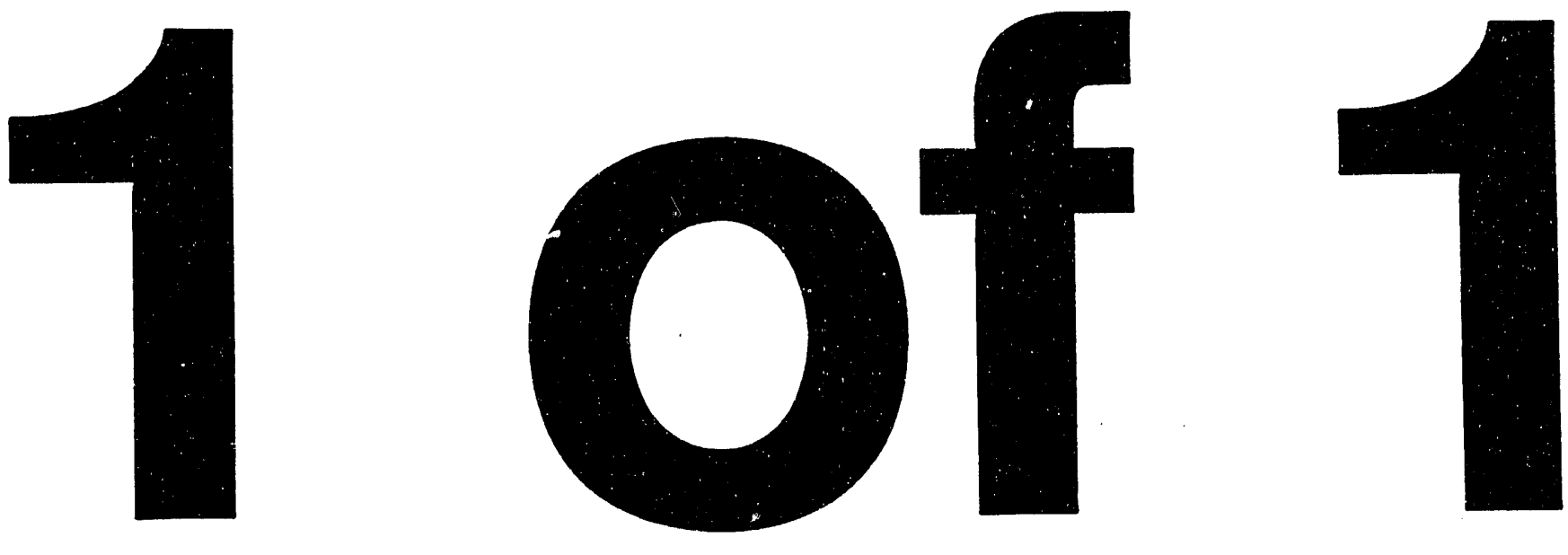


\title{
A Quality Control Program for Waste Disposal Vault Closure
}

\author{
H. L. Benny
}

Date Published

July 1994

To Be Presented at

Twenty-First Annual National Energy and

Environmental Quality Division Conference

Tucson, Arizona

September 18-21, 1994

Prepared for the U.S. Department of Energy Office of Environmental Restoration and

Waste Management

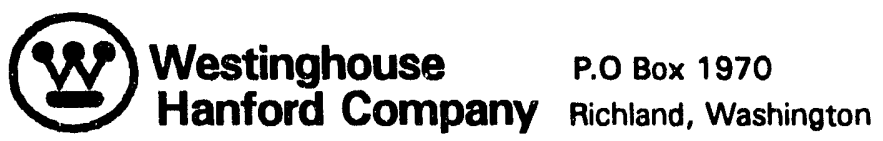

Hanford Operations and Engineering Contractor for the

U.S. Department of Energy under Contract DE-ACO6-87RL10930

Copyright Lbanes By acceptence of this erticle, the publisher end/or recipient acknowledges the

U.S. Government's right to retein a nonexclusive, royalty-fres license in and to any copyright covering this peper. 
TWENTY-FIRST ANNUAL NATIONAL ENERGY AND ENVIRONMENTAL QUALITY DIVISION CONFERENCE

HAZARDOUS WASTE STORAGE MANAGEMENT

A QUALITY CONTROL PROGRAM FOR WASTE DISPOSAL VAULT CLOSURE

Harold L. Benny

Manager, Geotechnical Engineering Laboratory

\author{
Westinghouse Hanford Company \\ P. O. Box 1970 \\ Richland, Washington 99352
}

\begin{abstract}
This paper provides a review of the quality control program employed for closure of a radioactive waste disposal vault at Hanford Washington. The major elenents of the program are discussed, as well as the testing results and lessons learned.

At the U.S. Department of Energy's Hanford Reservation, near Richland, Washington, a partially filled underground waste disposal vault required closure. The vault, approximately $15 \mathrm{~m}$ wide, $10 \mathrm{~m}$ deep, and $38 \mathrm{~m}$ long, contained approximately 6000 cubic meters of solidified radioactive waste. During disposal operations, the facility was managed as a surface impoundment, which required that the vault only be filled to within 1 meter of the top. After the waste in the vault solidified, the vault was to be closed under landfill requirements. This required filling of all void space within the vault. A grout slurry, developed by the
\end{abstract}


U.S. Army Corps of Engineers (1) was used as the void-fill material. The grout slurry was pumped into the vault (2) through a series of risers in the vault roof that were specially designed for this purpose. These risers, 24 in all, were spaced approximately every 4 meters, in three rows 5 meters apart. The grout was required to flow up to 6 meters without segregating or setting up. Thus, the flow characteristics of the grout, as a function of time, were very important in both the mix design process and actual placement. Additionally, the grout could not shrink as it cured, as this would leave void space and allow future subsidence of the overburden. In order to minimize shrinkage, the grout was to be placed in four layers. By allowing the grout to cure before placing the next layer, any shrinkage could be compensated for by the succeeding layer.

An additional constraint was imposed by the grout vendor. Because the grout mix contained large amounts of clay, it would interfere with their normal operations. Residual grout left in the mixer would affect the quality of normal concrete. Therefore, all void-filling batching and placement activities were conducted at night. This allowed the plant to reduce mixer washing, there was less traffic on the road which improved delivery times, and more trucks (10) were available. Because of the distance between the batch plant and the point of placement, trucks were taking 45 minutes on each leg of the trip. Added traffic during the day time would have made the transit time unacceptable.

Table 1 details the design requirements for the grout. Table 1. Void Fill Grout Design Requirements

\begin{tabular}{|c|c|c|}
\hline requil rement: & yethoo & specilification \\
\hline Flow & ASTM $C-939$ & $15-18$ sec \\
\hline Compressive strength & ASTM $C-109$ & 400 psi e 28 Days \\
\hline Bleed Water & GEL-37 & Zero \\
\hline Length Change & ASTM $C-157$ & $<0.18$ \\
\hline
\end{tabular}

Prior to initiating closure activities, a Quality control Program was needed to ensure that the materials, grout batch plant, and placement methods and procedures would produce a grout that met design requirements, and that placement and QC personnel were properly trained, equipped and prepared to support vault void filling operations.

A written quality control plan (3) was prepared and approved to guide the field operations. The plan detailed the following activities: 


\author{
Safety \\ Pre-Placement Qua] ification \\ Equipment Demonstration \\ QC Inspector Requirements \\ Placement Quality Activities \\ Post Placement Activities \\ Records
}

\title{
safety
}

Although no unique safety concerns were identified, personnel were briefed on the Batch plant and Vault operations. In addition, hazards associated with heavy equipment (noise, pinch points) were reviewed. Radiation exposures were detailed, and higher hazard areas were roped off and clearly posted.

\section{Pre-Placement oualifications}

Pre-Placement $Q C$ activities were used to verify that appropriate materials were available and that the batch plant, transport, and placement operations and equipment would not negatively affect the quality of the void-fill grout. The pre-placement $Q C$ activities consisted of the following:

- Obtaining Certified Material Test Reports (CMTRs) for the cement, flyash, bentonite clay, and admixtures. The CMTRs must verify that the materials meet the specifications.

- Test sand for conformance with ASTM C404, Natural Sand Size No. 2. No material may be retained by a No. 8 sieve. Verify that the sand is obtained from the Hanford Area.

- Obtain archive samples of each materia.

- Document National Ready Mix Concrete Association (NRMCA) Certification of batch plant vendor.

- Conduct a batch plant inspection to verify the batch plant equipment, materials handling practices, records, and personnel are adequate to support the project.

\section{Equipment Demonstration}

A small demonstration placement was used to test batching, transport, and placement equipment prior to actual void-fill material placement at the grout vault. Quality Control testing wac used during the demonstration to verify 
that the batch plant, transport, and placement equipment can be used to prc duce a consistent void-fill material meeting the required specifications. For this reason, all reasonable efforts were taken to ensure that the demonstration placement conditions replicate those anticipated for the vault placement (e.g., materials, transport time, placement equipment, and temperature). Table 2 identifies the $\mathrm{QC}$ tests that were conducted during the demonstration placement.

Table 2. Quality Control Testing During Demonstration Placement

\begin{tabular}{|c|c|c|c|c|}
\hline \multirow{2}{*}{ OUAIITIY coNTRRTI. } & & & \multirow[t]{2}{*}{ PROCEDURE } & \multirow{2}{*}{ I ACCEPTANCB } \\
\hline & $\mathrm{BrTCH}$ & PLACAMENT & & \\
\hline Unit Weight & 3/Batch & 3/Truck & GEL-11 & TBD \\
\hline Flow & 3/Batch & 3/Truck & GEL-12 & 15-18 sec. \\
\hline $\begin{array}{c}\text { Compressive } \\
\text { strength }\end{array}$ & 3/Batch & 3/Truck & GEL-05 & $\begin{array}{c}400 \mathrm{psi} \text { at } 28 \\
\text { day }\end{array}$ \\
\hline Temperature & 3/Batch & 3/Truck & GEL-12 & $<90 \mathrm{C}$ \\
\hline Sand Suspension & 3/Batch & 3/Truck & N/A & $N / A$ \\
\hline Sand Moisture & 2/Day & $N / A$ & GEL-11 & $\mathbf{N} / \mathbf{A}$ \\
\hline
\end{tabular}

\section{Quality control Inspector Requirements}

The QC plan spelled out the QC Inspector responsibilities, qualifications, and authority. The inspectors were responsible for all sampling, testing, and inspections. They were trained to written procedures and were required to demonstrate proficiency prior to conducting QC testing. This was documented during the equipment demonstration, at both the batch plant and field locations. Two lead inspectors were designated to approve or reject grout materials, and batches, and could specify additional testing requirements as necessary.

\section{Placement ouality control}

Placement QC activities were used to ensure that (1) batch plant, transport, and placement activities are conducted appropriately; and (2) the delivered grout material is within the specified criteria. Testing and surveillance were conducted both at the batch plant and at the placement site. During placement, a quality control inspector was maintained at the batch plant at all times. Table 3 identifies the testing that was conducted at the batch plant during placement. 
Table 3. Quality Control Testing During Void-Fill Placement

\begin{tabular}{|c|c|c|c|c|}
\hline \multirow{2}{*}{$\begin{array}{l}\text { QUALITY CONTROL } \\
\text { TEST/ ACTIVITY }\end{array}$} & \multirow[b]{2}{*}{ BATCH } & \multirow[b]{2}{*}{ PLACEMENT } & \multirow[t]{2}{*}{ PROCEDURE } & \multirow{2}{*}{$\begin{array}{l}\text { ICCEPTANCH. } \\
\text { SPECIFTCATION }\end{array}$} \\
\hline & & & & \\
\hline Unit Weight & $50 \mathrm{Yd}^{3}$ & $50 \mathrm{Yd}^{3}$ & GEL-11 & TBD \\
\hline Flow & $50 \mathrm{Yd}^{3}$ & $50 \mathrm{Yd}^{3}$ & GEL-12 & 15-18 Sec. \\
\hline Temperature & $50 \mathrm{Yd}^{3}$ & $50 \mathrm{Yd}^{3}$ & GEL-12 & $<90 \mathrm{~F}$ \\
\hline Sand Suspension & $50 \mathrm{Yd}^{3}$ & $50 \mathrm{Yd}^{3}$ & $\mathrm{~N} / \mathrm{A}$ & N/A \\
\hline Sand Moisture & $2 / \mathrm{Day}^{3}$ & $N / A$ & GEL-11 & $N / A$ \\
\hline Bleed Water & $\mathrm{N} / \mathrm{A}$ & $50 \mathrm{Yd}^{3}$ & GEL-XX & Zero \\
\hline Shrinkage & $\mathrm{N} / \mathrm{A}$ & $50 \mathrm{Yd}^{3}$ & GEL-21 & $<0.18$ \\
\hline $\begin{array}{c}\text { Compressive } \\
\text { strength }\end{array}$ & N/A & $50 \mathrm{Yd}^{3}$ & GEL-05 & $\begin{array}{c}400 \text { psi at } 28 \\
\text { Days }\end{array}$ \\
\hline
\end{tabular}

\section{Post-Placement Activities}

Post-placement QC activities consist of (1) completing the bleed water, length change, and compressive strength tests initiated during placement, anci (2) preparing the final $Q C$ report. The laboratory tests were completed in accordance with the procedures identified in Table 3. The content of the final QC report was specified.

\section{Records}

Copies of all pertinent records were maintained in the project file in accordance with DOE Records Management Program. A copy of all records were included in the final $Q C$ report. These records included:

- Certified Material Test Reports for the void fill grout

- Documentation of the batch plant NRMCA certification

- Documentation of the batch plant inspection results

- Calibration records for batch plant and testing equipment

- Test data sheets and records

- Field notes recorded during batching and placement

- Training records for all QC inspections 


\section{Results}

The results of the quality control tests are shown in tables 4, 5, 6, and 7 for each of the four placements.

It can be seen that some of the flow times were out of specifications. These batches were accepted as is, due to the difficulty in performing this test. During mixing, some of the clay was left in small lumps, which clogged the flow cone, resulting in the flow time appearing longer than acceptable. These grout loads were accepted, based on visual inspection of the grout in the pump hooper, and by observing the grout flowing inside the vault via remote camera.

For the October 10 placement, excessive shrinkage was experienced. These were accepted as is. The placement cured for eleven days before the next pour, thereby compensating for the shrinkage.

\section{Lessons Learned}

Dealing with a clay-rich grout caused some problems in the field, especially dealing with lumps of clay. The decision was made to strain all grout prior to testing to eliminate these lumps, but this was not representative of actual placement conditions.

More testing to develop better mixing and batching methods would probably reduce this problem. Some modifications to the batching sequence were tried, but standard concrete batching equipment is not the best for this type of grout. Few noticeable changes occurred due to changes in batching sequences, or mixing durations.

Table 4. October 05 Placement Test Results

\begin{tabular}{|c|c|c|c|c|}
\hline sample $/$ & $\begin{array}{l}28 \text { Day Compresilive } \\
\text { Strength }\end{array}$ & Expansion & P10W & trea water \\
\hline 3 & $1020 \mathrm{pgi}^{1}$ & 0.028 & $14.0 \mathrm{~g}^{2}$ & 0 \\
\hline 4 & $1080 \mathrm{pgi}$ & 0.0058 & $18.5 \mathrm{~g}$ & 0 \\
\hline 5 & $2100 \mathrm{pgi}$ & 0.108 & $15.5 \mathrm{~g}$ & 0 \\
\hline 6 & $1150 \mathrm{pgi}$ & 0.038 & $17.0 \mathrm{~s}$ & 0 \\
\hline 7 & $840 \mathrm{psi}$ & 0.048 & $13.8 \mathrm{~g}$ & 0 \\
\hline 8 & $750 \mathrm{pgi}$ & 0.0158 & $14.5 \mathrm{~g}$ & 0 \\
\hline 9 & $1070 \mathrm{psi}$ & 0.148 & $13.1 \mathrm{~s}$ & 0 \\
\hline 10 & $710 \mathrm{pg} 1$ & 0.058 & $15.0 \mathrm{~g}$ & 0 \\
\hline 11 & $790 \mathrm{psi}$ & 0.008 & $15.1 \mathrm{~B}$ & 0 \\
\hline
\end{tabular}

pounds per square inch seconds 
Table 5. October 10 Placement Test Results

\begin{tabular}{|c|c|c|c|c|}
\hline $58 m p 1 e \cdot$ & 28 pay compresoly & nxpans $10 n$ & $04 \% w$ & rros rater \\
\hline 12 & $670 \mathrm{psi}^{2}$ & -0.9958 & $14.0 \mathrm{~g}^{2}$ & 0 \\
\hline 13 & $770 \mathrm{psi}$ & -0.888 & $17.4 \mathrm{~s}$ & 0 \\
\hline 14 & $1090 \mathrm{psi}$ & -0.5058 & $15.0 \mathrm{~s}$ & 0 \\
\hline 15 & $810 \mathrm{psi}$ & -1.038 & $17.0 \mathrm{~s}$ & 0 \\
\hline 16 & $1260 \mathrm{psi}$ & -1.018 & $18.5 \mathrm{~s}$ & 0 \\
\hline 17 & $820 \mathrm{pgi}$ & -0.038 & $15.2 \mathrm{~g}$ & 0 \\
\hline 18 & $850 \mathrm{psi}$ & $\mathrm{NT}^{3}$ & $15.0 \mathrm{~s}$ & 0 \\
\hline 19 & $795 \mathrm{pgi}$ & NT & $19.5 \mathrm{~s}$ & 0 \\
\hline 20 & $680 \mathrm{pgi}$ & NT & $16.6 \mathrm{~s}$ & 0 \\
\hline
\end{tabular}

pounds per square inch

seconds

no test - specimen broke during de-molding

Table 6. October 21 Placement Test Results

\begin{tabular}{|c|c|c|c|c|}
\hline $84 m p 18 \%$ & 28 pay compress 1 ve & Expanston & P1ow & fres hater \\
\hline 21 & $960 \mathrm{psi}^{1}$ & 0.238 & $16.2 \mathrm{~s}^{1}$ & 0 \\
\hline 22 & $590 \mathrm{pgi}$ & $0.15 \%$ & $24.3 \mathrm{~B}$ & 0 \\
\hline 23 & $620 \mathrm{psi}$ & 0.288 & $16.0 \mathrm{~s}$ & 0 \\
\hline 24 & $650 \mathrm{pgi}$ & $\mathrm{NT}^{3}$ & $13.5 \mathrm{~g}$ & 0 \\
\hline 25 & $750 \mathrm{psi}$ & 0.438 & $15.8 \mathrm{~s}$ & 0 \\
\hline 26 & 760 psi & $N T$ & $15.8 \mathrm{~g}$ & 0 \\
\hline 27 & $660 \mathrm{psi}$ & NT & $13.5 \mathrm{~s}$ & 0 \\
\hline
\end{tabular}

pounds per square inch

seconds

no teat - specimen broke during de-molding 


$$
\text { WHC-SA-2559-FP }
$$

Table 7. October 28 Placement Test Results

\begin{tabular}{|c|c|c|c|c|}
\hline samp $1 \odot$ & 28 pay compresilye & Expanston & Plow & rros hater \\
\hline 28 & $800 \mathrm{psi}^{1}$ & $0.05 \%$ & $15.5 \mathrm{~g}^{2}$ & 0 \\
\hline 29 & $800 \mathrm{ps} 1$ & 0.088 & $14.0 \mathrm{~g}$ & 0 \\
\hline
\end{tabular}

pounds per square inch

2 seconds

\section{Beferences}

Wakeley, L. D. and Ernze, J. J., 1992, Grout for Closure of the Demonstration Vault at the US DOE Hanford Facility, Technical Report.

Phillips, S. J., R. G. Alexander, J. L. England, W. E. Stewart, K. W. Bledsoe, J. L. Foster, D. J. Tedeschi, and J. L. Vigue, 1994, "Radioactive Waste Vault Closure: Geotechnical Operations," WHC-SA-2262-S, SPECTRUM 94, Atlanta, GA.

Crane, P. J., 1993, Quality Control Plan for PSW Vault Void Fil1, WHC-SD-WM-TP-152, Westinghouse Hanford Company, Richland, WA. 
WHC-SA-2559-FP

\section{DI8TRIBUTION}

Number of copies

ONSITE

3

Westinghouse Hanford Company

$\begin{array}{ll}\text { H. L. Benny } & \text { L7-09 } \\ \text { Information Release } & \\ \text { Administration (2) } & \text { L8-07 }\end{array}$

Distr-1 

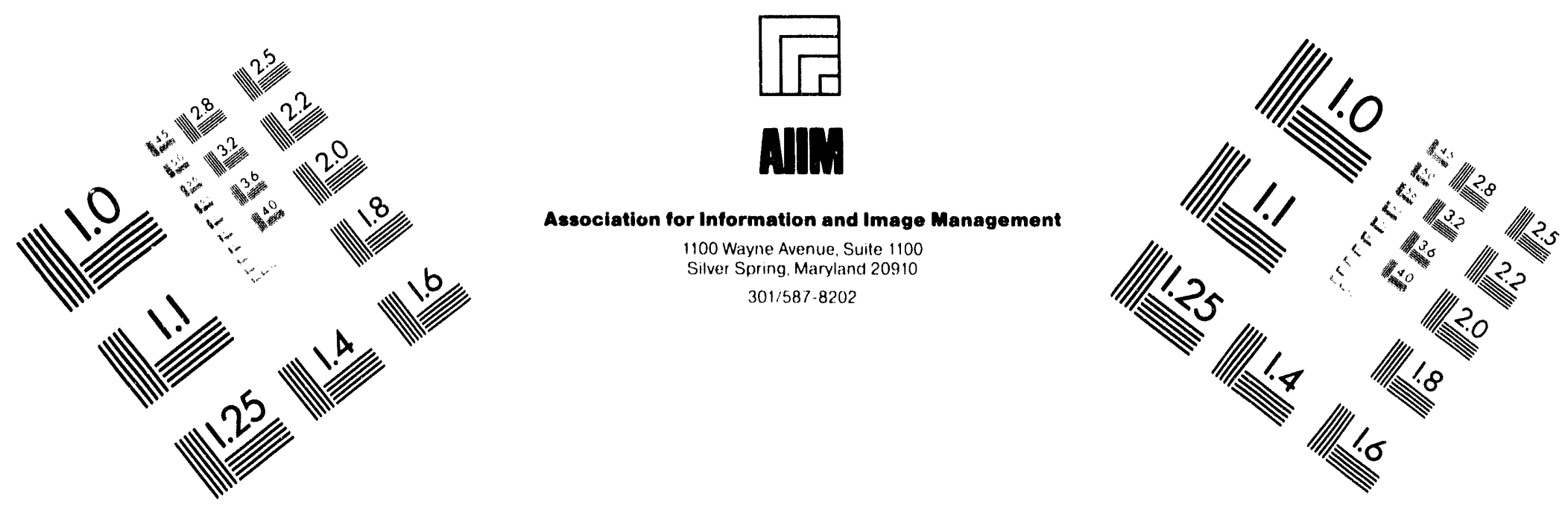

\section{Centimeter}

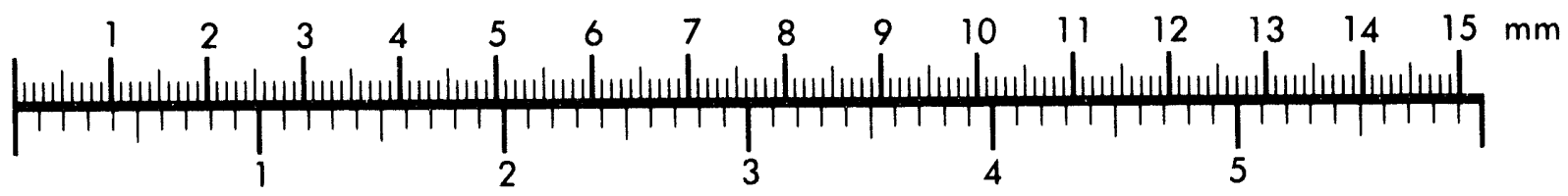
Inches
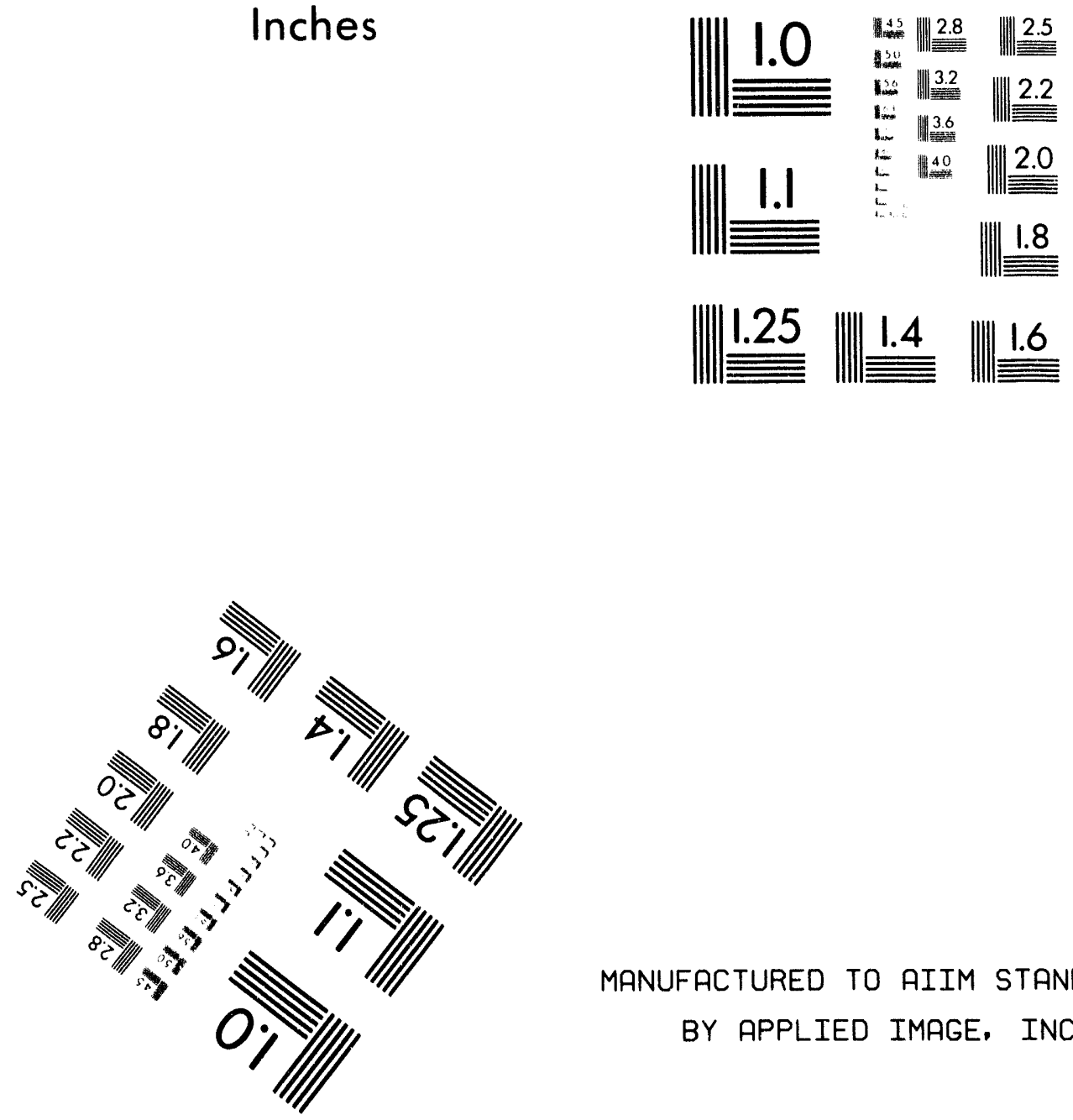

MANUFACTURED TO AIIM STANDARDS

BY APPLIED IMAGE, INC.

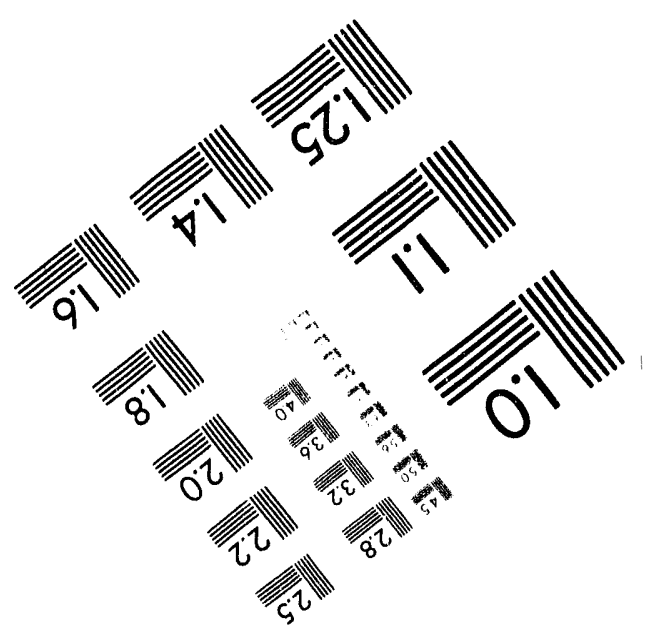




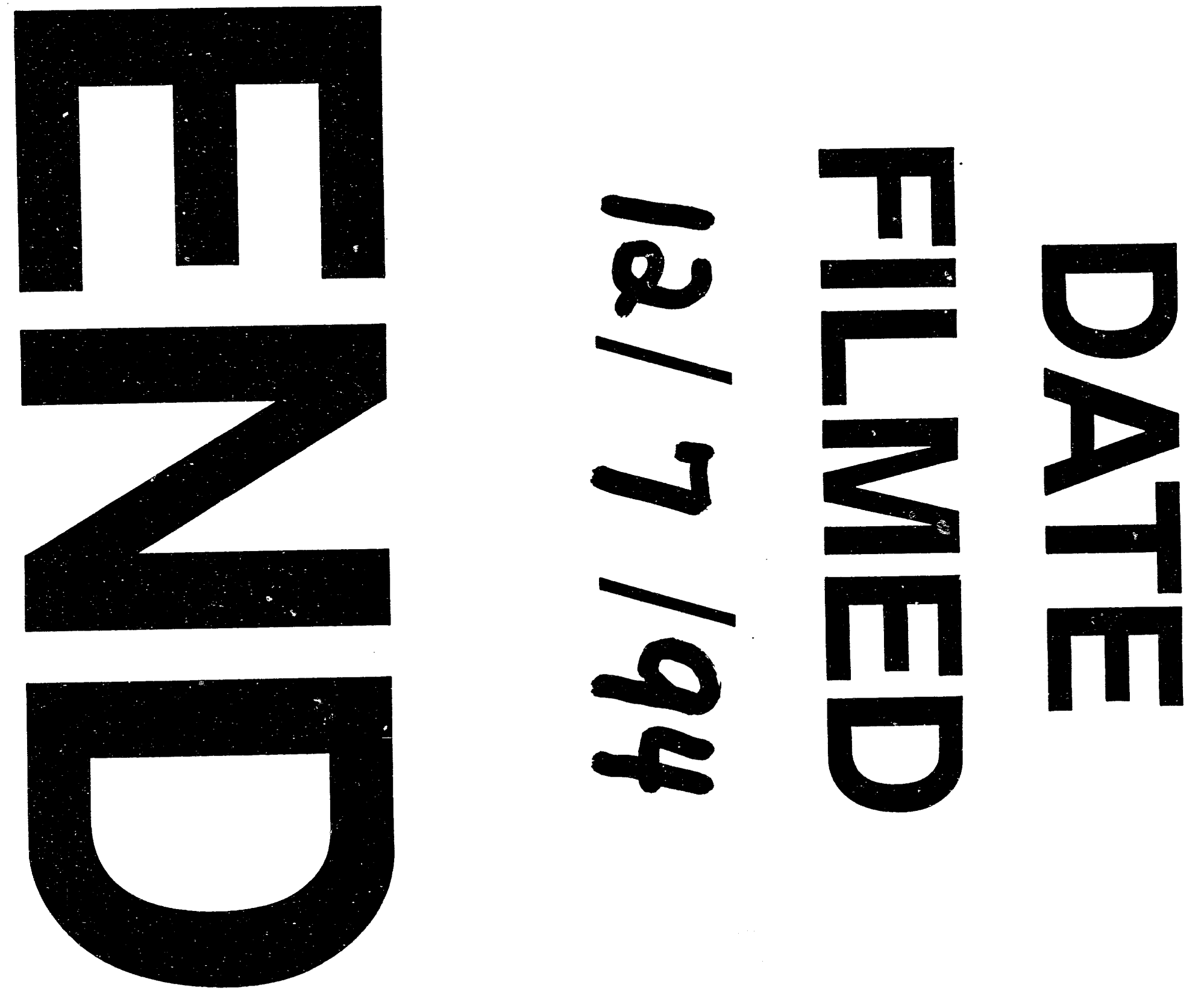